Original Article

\title{
Prevalence of gastrointestinal parasite in small ruminants of District Dir Upper Khyber Pakhtunkhwa Province of Pakistan
}

\author{
Prevalência de parasita gastrointestinal em pequenos ruminantes do distrito Upper \\ Dir, da província de Khyber Pakhtunkhwa, no Paquistão
}

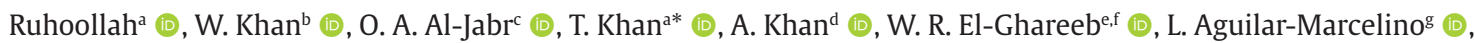 \\ E. O. S. Hussein ${ }^{\text {h }}$, A. R. Alhimaidi i (D) and A. A. Swelum ${ }^{\text {h.j }}$ (D) \\ aVirtual University of Pakistan, Department of Molecular Biology, Lahore, Pakistan \\ bUniversity of Malakand, Department of Zoology, Chakdara, Dir Lower, KPK, Pakistan \\ 'King Faisal University, College of Veterinary Medicine, Department of Microbiology, Al-Ahsa, Saudi Arabia \\ dAbdul Wali Khan University, Department of Zoology, Mardan, Pakistan \\ eKing Faisal University, College of Veterinary Medicine, Department of Public Health, Al-Ahsa, Saudi Arabia \\ Zagazig University, Faculty of Veterinary Medicine, Department of Food Control, Zagazig, Egypt \\ gInstituto Nacional de Investigaciones Forestales Agricolas y Pecuarias - INIFAP, Centro Nacional de Investigación Disciplinaria en Salud Animal \\ e Inocuidad, Col. Progreso, Jiutepec, Morelos, México. \\ hKing Saud University, College of Food and Agriculture Sciences, Department of Animal Production, Riyadh, Saudi Arabia \\ iKing Saud University, College of Sciences, Department of Zoology, Riyadh, Saudi Arabia \\ iZagazig University, Faculty of Veterinary Medicine, Department of Theriogenology, Zagazig, Egypt
}

\begin{abstract}
The present research was planned to assess the occurrence of intestinal parasites in small ruminants of Upper Dir of Khyber Pakhtunkhwa Province of Pakistan. For this purpose, the faecal material was collected randomly with gloved fingers directly from the rectum region of sheep and goats and the faecal materials were then put in hygienic plastic bottles with $10 \%$ formalin. The overall 315 ( $n=184$ sheep and $n=131$ goats) faecal samples were collected out of 315 samples, 281 were found positive for different parasites. Patterns-wise prevalence of GI parasites of the study area was found. Overall Single parasitism $89.20 \%$ (281/315) with $94.0 \%$ (173/184) in sheep and 82.43\% (108/131) in goats. Double parasitic infection in small ruminant recorded in which Fasciola+ Haemonchus. contortus in sheep were found their prevalence was $25.54 \%$ (47/184). While in goats, the double parasitic infection in which Haemonchus contortus+Trichuris spp were found and their prevalence were $23.43 \%$ (30/131). The species found in the sample of sheep were includes, i.e., Strongyloides papillosus (41.30\%), Heamonchus controtus (21.73\%), Trichuris ovis (17.39\%), and Fasciola hepatica (13.58\%), the corresponding value for goat were Strongyloides spp 33.33\% (36/108), Haemonchus spp 28.70\%, (27/108), Trichuris spp $25.20 \%$ (27/184) and Fasciola spp $10.68 \%(14 / 184)$. The sheep of the study area are more infected as compared to goats. This study suggested that gastrointestinal parasites are major health problems of small ruminants in the study area. Therefore, a comprehensive study on species of gastrointestinal parasites circulating in the area, control options, cost-effective strategies and awareness about gastrointestinal parasites among the farmers in the study area should be instituted.
\end{abstract}

Keywords: Fasciola spp., Heamonchus spp., prevalence, Strongyloides.

\begin{abstract}
Resumo
A presente pesquisa foi planejada para avaliar a ocorrência de parasitas intestinais em pequenos ruminantes do distrito Upper Dir, da província de Khyber Pakhtunkhwa, no Paquistão. Para tanto, o material fecal foi coletado aleatoriamente com dedos enluvados diretamente da região do reto de ovelhas e cabras, e os materiais fecais foram colocados em garrafas plásticas higiênicas com formol a 10\%. No total, 315 ( $n=184$ ovelhas e $n=131$ cabras) amostras fecais foram coletadas; destas, 281 foram consideradas positivas para diferentes parasitas. A prevalência de padrões de parasitas GI da área de estudo foi encontrada. Parasitismo global único 89,20\% (281/315) com 94,0\% (173/184) em ovinos e 82,43\% (108/131) em cabras. Infecção parasitária dupla em pequenos ruminantes registrada em Fasciola + Haemonchus contortus em ovinos, sua prevalência foi de 25,54\% (47/184). Já em caprinos, a dupla infecção parasitária em que Haemonchus contortus + Trichuris spp foram encontrados e sua prevalência foi de 23,43\% (30/131). As espécies encontradas na amostra de ovinos foram: Strongyloides papillosus (41,30\%), Heamonchus controtus (21,73\%), Trichuris ovis (17,39\%) e Fasciola hepatica (13,58\%), o valor correspondente para cabra foi Strongyloides spp. 33,33\% (36/108), Haemonchus spp. 28,70\%, (27/108), Trichuris sp 25,20\% (27/184) e Fasciola spp. 10,68\% (14/184). As ovelhas da área de estudo estão mais infectadas do que as cabras. Este estudo sugeriu que os parasitas gastrointestinais são os principais problemas de saúde dos pequenos ruminantes na área de estudo. Portanto, um estudo abrangente sobre as espécies de parasitas gastrointestinais que circulam na área, opções de controle, estratégias de baixo custo e conscientização sobre parasitas gastrointestinais entre os agricultores na área de estudo deve ser instituído.
\end{abstract}

Palavras-chave: Fasciola spp., Heamonchus spp., prevalência, Strongyloides.

*e-mail: Tawseefkhan055@gmail.com

Received: February 23, 2021 - Accepted: June 10, 2021

This is an Open Access article distributed under the terms of the Creative Commons Attribution License, which permits unrestricted use, distribution, and reproduction in any medium, provided the original work is properly cited. 


\section{Introduction}

Gastrointestinal parasites cause mortalities, production loss, and weight loss in small ruminants (goats and sheep), thereby impeding their production system. Small ruminants (goat and sheep) constitute a significant portion of livestock in a country (Siddiki et al., 2009). Livestock has greater importance in raising the financial position of a country because livestock is the chief source of protein, and their products like skin, bones, and many goods are made from the fetch of these animals (Gupta et al., 1987). Common abdominal parasites of livestock are coccidia species of phylum protozoa. Trematodes belong to flukes, nematodes commonly called roundworms, cestodes famous on tapeworms, while the most abundant nematodes in small ruminants are Tricho Strongyloides which their prevalence are worldwide (Awraris et al., 2012). Nematodes have a single host life cycle in small or large ruminant's guts to complete their life cycle (Scott and Sutherland, 2009). Nematode's infections are very significant economically that are the leading agents for poor growth and insufficient production. Livestock are highly susceptible to different infections of these nematodes (Lashari and Tasawar, 2011), Paramphistomiasis, Fascioliasis, Tricho strongylosis, Haemonchosis and oesophagostomiasis GI parasitism can affect the growth and production of livestock (Speedy, 1992). Haemonchosis cause serious mortalities in sheep and goats also cause significant loses if there is no treatment programmes and appropriate monitoring of parasites (Besier et al., 2016). Trematodes are endoparasites that have indirect life cycles with one or more intermediate host's molluscs (Berra and Au, 1978). Parasites of trematodes are universally distributed in ruminants' animals and have attained a high zoological position in the world (Rafique et al., 2009). The common fluke's Fasciola hepatica lives in the liver of sheep and causes fascioliasis. Fasciola hepatica intends countless financial harm that are universally discrete classes (Irfanullah et al., 2016).
Mature trematodes parasitic infection in animals that are the basis to infection in sheep and goats remain dependent on the geographic diversity of chosen class everywhere. Scientific suggestions about trematodes infection clinical symptoms, which are typically happening in hot regions of the biosphere, contain weakness, weight loss, reduce milk manufacture, water-logged, decreasing quality, watery diarrhoea, decrease in the number of products, and even death caused by parasites (Gupta et al., 1987).

No evidence is accessible of parasites of goats and sheep in the present region. This evidence with suggestion is primarily essential for the identification and prevalence of parasitic disease that provides significant understanding for investigation and prevalence of helminthiasis in Dir upper. Therefore, this current research was aimed at examining and the occurrence of the different parasites found in the Gastrointestinal tract of both goat and sheep of Dir upper District of KPK.

\section{Methods and Materials}

\subsection{Study area}

The total area of District Upper Dir is 3699 square kilometers. It is situated with latitudes and longitudes of $35^{\circ}$ and $71^{\circ} \mathrm{N}$, respectively. Geographically upper Dir district is situated on the north side of Pakistan. This district is surrounded in North West by district Chitral, west by Bajwar agency, in the south by district Dir lower, while in the East by Swat district see (Figure 1) Mostly district Dir upper is covered with high mountains and hills. In contrast, there is no plain area in the study region.

\subsection{Study population}

The study population consisted of all goats and sheep in the study area.

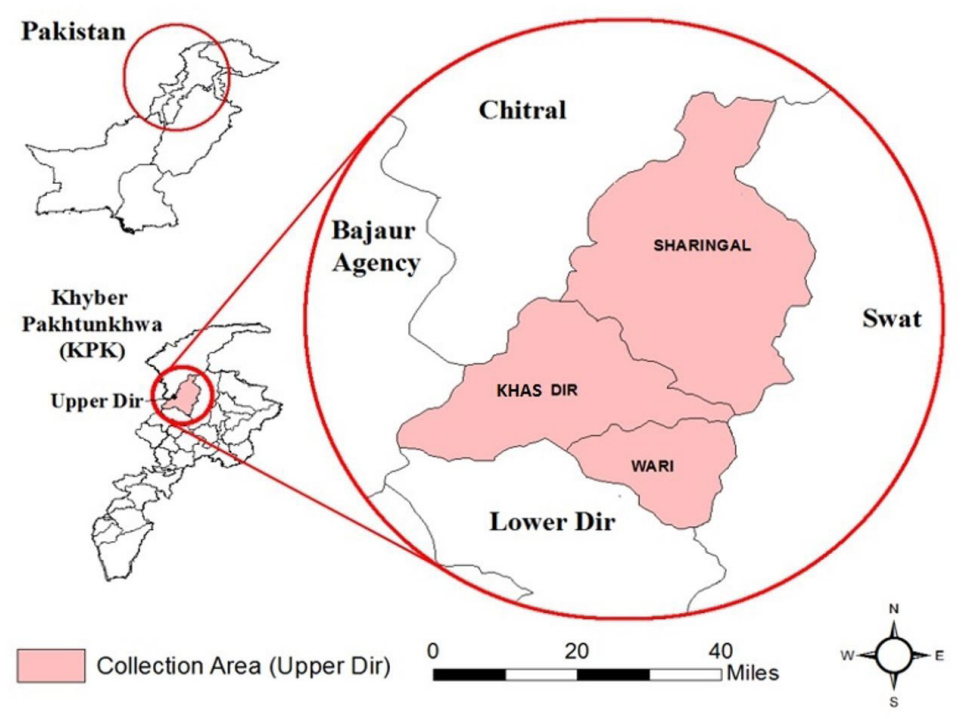

Figure 1. Map of Study area Dir Upper KPK Pakistan. 


\subsection{Samples collection}

Faecal samples were collected from upper Dir districts of the three most populated regions as Wari, Khas Dir, and Sharingal.

\subsection{Direct smear methods (wet mount techniques)}

\subsubsection{Normal saline solution}

A solution of the saline wet mount was made in which 2 grams of faces were mixed within the drop of saline upon a glass slide. A light microscope was used for smear examination as described by Urquhart et al. (1987).

\subsection{Sedimentation technique}

The sedimentation technique was used to detect some parasites' eggs like trematodes eggs are larger than other parasitic eggs; therefore, these eggs settled down quickly in the test tube when centrifuged with a solution of $\mathrm{NaCl}$. After this, a drop of settled down material put on the slides with a drop of $\mathrm{NaCl}$ and examined under the microscope at $4 \mathrm{x}$ and $10 \mathrm{x}$ ranges, respectively.

\subsection{Statistical analysis}

Statistically, analysis conducted using SPSS 16.0. The comparative occurrence of dissimilar gastrointestinal (GI) parasites class or individuals correspondingly measured as (\%) of prevalence $=($ numbers of + samples/Total numbers of samples studied) $x 100$. The evocative information gotten examined over manifold log deteriorations for the measurement of significance of association determined like age of species sex and ecology of occurrence and gastrointestinal parasites in small ruminants (Sajid et al., 2009).

\section{Results}

The current study is based on the identification and prevalence of gastrointestinal parasites in small ruminants (goats and sheep) in District Upper Dir. It has not been reported previously by any other author of the mentioned area. Overall, in this present study, 312 ( $\mathrm{n}=184$ sheep and $\mathrm{n}=131$ goats) were collected in Upper Dir Pakistan (Table 1).

The overall prevalence of helminth parasites was reported $89.20 \%$ (281/315) with $94 \%$ (173/184) in sheep and $82.43 \%(108 / 131)$ in goats with the occurrence percentage of Strongyloides papilliousus 41.30\% (76/184), Haemonchus contortous $21.73 \%$ (40/184), Trichuris ovis $17.39 \%$ (32/184) and Fasciola hepatica 13.58\%(25/184) in sheep while the prevalence of Strongyloides Papiliosus 33.33\% (36/131), Haemonchus contortous $28.70 \%$ (27/131), Trichuris ovis $25.20 \%$ (27/131) and Fasciola hepatica 10.68\%(14/131) in goats were found (Table 1).

Patterns wise prevalence of GI parasites of the study area were found in single parasitism $89.20 \%(281 / 315)$ with $94.0 \%$ (173/184) in sheep and $82.43 \%$ (108/131) in goats with the occurrence of Strongyloides spp 41.3\% (76/184), Haemonchus spp $24.77 \%$ (40/184), Trichuris spp 17.39\% (32/184) and Fasciola spp 13.58\% (25/184) in sheep while the prevalence of Strongyloides spp 27.48\% (36/131), Haemonchus spp 23.39\% (33/131), Trichuris spp 21.37\% (28/131) and Fasciola spp $8.39 \%(11 / 131)$ in goats were found (Table 2$)$

Table 1. Prevalence of helminth parasite in sheep and goats grazing in hilly areas of District Dir Upper Pakistan.

\begin{tabular}{|c|c|c|c|c|c|}
\hline \multirow[b]{2}{*}{ Parasites } & \multicolumn{2}{|c|}{ Sheep $(n=184)$} & \multicolumn{2}{|c|}{ Goats (n=131) } & \multirow[b]{2}{*}{ Overall (\%) } \\
\hline & $\begin{array}{c}\text { No of Samples } \\
\text { positive }\end{array}$ & Infection (\%) & $\begin{array}{l}\text { No.of samples } \\
\text { Positive }\end{array}$ & Infection (\%) & \\
\hline $\begin{array}{c}\text { Strongyloides } \\
\text { papillosus }\end{array}$ & 76 & 41.30 & 36 & 33.33 & $112 / 315(35.55)$ \\
\hline $\begin{array}{l}\text { Haemonchus } \\
\text { contortous }\end{array}$ & 40 & 21.73 & 31 & 28.70 & $71 / 315(22.53)$ \\
\hline Trichuris ovis & 32 & 17.39 & 27 & .25 .20 & $57 / 315(18.09)$ \\
\hline Fasciola hepatica & 25 & 13.58 & 14 & 10.68 & $39 / 315(12.38)$ \\
\hline Total & 173 & 94.0 & 108 & 82.43 & $281 / 315(89.20)$ \\
\hline
\end{tabular}

Table 2. Pattern wise Single parasitic infection among sheep and goats in District Dir upper.

\begin{tabular}{|c|c|c|c|c|c|}
\hline \multirow[b]{2}{*}{ Parasites } & \multicolumn{2}{|c|}{ Sheep (n=184) } & \multicolumn{2}{|c|}{ Goats (n=131) } & \multirow[b]{2}{*}{ Overall (\%) } \\
\hline & $\begin{array}{c}\text { No of +eve } \\
\text { Samples }\end{array}$ & Infection (\%) & Positive Samples & Infection (\%) & \\
\hline Strongyloides spp & 76 & 41.30 & 36 & 27.48 & $112 / 315(35.55)$ \\
\hline Haemonchus spp & 40 & 21.73 & 33 & 25.19 & $71 / 315(22.53)$ \\
\hline Trichuris spp & 32 & 17.39 & 28 & 21.37 & $57 / 315$ (18.09) \\
\hline Fasciola spp & 25 & 13.58 & 11 & 8.39 & $39 / 315(12.38)$ \\
\hline Total Parasites & 173 & 94.0 & 108 & 82.43 & $281 / 315(89.20)$ \\
\hline
\end{tabular}


Double parasitic infection in small ruminant of District Upper Dir recorded in two categories in sheep and goats first category for sheep in which Fasciola+ Haemonchus. contortus were included, their prevalence were25.54\% (47/184), and the second category in which trichuris. Ovis+ Haemonchus. Contortus were included, their prevalence recorded $22.82 \%$ (42/184), while in Goats, the triple parasitic infection of the first category in which Haemonchus contortus+Trichuris spp were included and their prevalence were $23.43 \%$ (30/131) and the second category in which Haemonchus. contortus +stryngile were recorded, their prevalence was $18.75 \%$ (24/131) see (Table 3 )

Triple parasitic infection in sheep of District Upper Dir recorded in two categories in sheep and goats first category for sheep in which Fasciola spp $+H$. contortus $+T$. ovis were included their prevalence was $20.10 \%$ (37/184). In the second category in which Trichuris spp + Haemonchus spp+Strongyle were included, their prevalence recorded 25.54\% (47/184). In contrast, in Goats, the triple parasitic infection of the first category in which $\mathrm{H}$. Contortus + Trichuris spp, Strongyle spp were included and their prevalence were 26.56\% (34/184) and the second category in which Haemonchus spp+Strongyle spp+Faciola spp were recorded, their prevalence was $17.96 \%$ $(23 / 131)$ see (Table 4)

\section{Discussion}

This present research work showed the overall occurrence of the parasite in sheep and goat that were 94.0\% $(n=173 / 184$ and $89.20 \%(n=108 / 131)$, respectively.
Different species of nematodes recovered during this investigation have already been reported by different researchers in different parts of the world (Pedreira et al., 2006; Nwosu et al., 2007; Lashari and Tasawar, 2011).

The prevalence recorded in the present study is lower than the study conducted by (Gadahi et al., 2009). They reported overall prevalence among the sample from the sheep $n=48$ (53.33\%) and $n=206(66.45 \%)$ from goat were detected positive for GI parasites. Thus the result of the present study is nearly similar to the study conducted by (Singh et al., 2017). They reported the prevalence rate of goat 212 (85.16\%) while in sheep 391 (79.24\%), the occurrence of gastrointestinal parasites tended to be higher in sheep 62 (72\%) than in goats 160(63\%) (Asif et al., 2008).

In risk factor Patterns wise prevalence of GI parasites of the study area was found in overall single parasitism $89.20 \%$ (281/315) with $94.0 \%$ (173/184) in sheep and $82.43 \%$ $(108 / 131)$ in goat with the occurrence of Strongyloides 41.3\% (76/173), Heamonchus spp 24.77\% (40/173), Trichuris spp 17.39\% (32/173) and Fasciola spp 13.58\% (25/173) in sheep while the prevalence of Strongyloides spp $27.48 \%$ (36/108), Heamonchus spp 23.39\% (33/108), Trichuris spp $21.37 \%$ (28/108) and Fasciola spp 8.39\% (11/108) in goat were found see (Table 2 ).

Similarly, a study conducted in various part of the world revealed that the result of the present study is nearly similar to the study conducted by (Gadahi et al., 2009). In their investigation, $53.33 \%$ prevalence for sheep and $66.45 \%$ prevalence for goat have observed in which most of the sample were positive with multiple infections than single

Table 3. Double parasitic infection among sheep and goat in District Dir upper Pakistan.

\begin{tabular}{|c|c|c|c|c|c|}
\hline \multirow[b]{2}{*}{ Parasites } & \multicolumn{2}{|c|}{ Sheep $(N=184)$} & \multirow[b]{2}{*}{ Parasites } & \multicolumn{2}{|c|}{ Goats $(\mathrm{N}=131)$} \\
\hline & $\begin{array}{c}\text { Positive } \\
\text { Samples (N) }\end{array}$ & Infection (\%) & & $\begin{array}{c}\text { Positive } \\
\text { Samples (N) }\end{array}$ & $\begin{array}{c}\text { Infected } \\
\text { Samples (\%) }\end{array}$ \\
\hline $\begin{array}{l}\text { Fasciola+Haemonchus. } \\
\text { Contortus }\end{array}$ & $47 / 184$ & 25.54 & $\begin{array}{c}\text { Haemonchus. } \\
\text { Contortus+Trichuris ovis }\end{array}$ & $30 / 131$ & 23.43 \\
\hline $\begin{array}{l}\text { Trichuris. Ovis+ } \\
\text { Haemonchus. } \\
\text { Contortus }\end{array}$ & $42 / 184$ & 22.82 & $\begin{array}{l}\text { Haemonchus.Contortus } \\
\text { +stryngelides }\end{array}$ & $24 / 131$ & 18.75 \\
\hline Total & $89 / 184$ & 48.36 & Total & $54 / 131$ & 42.18 \\
\hline
\end{tabular}

Table 4. Triple parasitic infection among sheep and goats in District Dir upper.

\begin{tabular}{|c|c|c|c|c|c|}
\hline \multirow[b]{2}{*}{ Parasites } & \multicolumn{2}{|c|}{ Sheep $(n=184)$} & \multirow[b]{2}{*}{ Parasites } & \multicolumn{2}{|c|}{ Goats (n=131) } \\
\hline & $\begin{array}{c}\text { Positive } \\
\text { Samples (n) }\end{array}$ & $\begin{array}{c}\text { No. Infected } \\
(\%)\end{array}$ & & $\begin{array}{c}\text { Positive } \\
\text { Samples (n) }\end{array}$ & $\begin{array}{c}\text { No. Infected } \\
(\%)\end{array}$ \\
\hline $\begin{array}{c}\text { Fasciola spp+ } \\
\text { Haemonchus spp } \\
\text { +Trichurus spp }\end{array}$ & $37 / 184$ & 20.10 & $\begin{array}{c}\text { Haemonchus + } \\
\text { Trichuris+Strongyle }\end{array}$ & $34 / 131$ & 26.56 \\
\hline $\begin{array}{c}\text { Trichuris spp + } \\
\text { Haemonchus } \\
\text { spp+Strongyle spp }\end{array}$ & $47 / 184$ & 25.54 & $\begin{array}{c}\text { Haemonchus+stryngile+ } \\
\text { Fasciola }\end{array}$ & $23 / 131$ & 17.96 \\
\hline Total & $84 / 184$ & 45.64 & Total & $57 / 131$ & 44.52 \\
\hline
\end{tabular}


infection 38 (42.22\%) and 156 (50.32) in sheep and goats respectively also study conducted by (Raza et al., 2014) reported their prevalence with significant $P$ value $=0.01$ in single infections of parasites.

In the current study, the double parasitic infection rate in goats and sheep was $48.36 \%(89 / 184)$ and $42.18 \%(54 / 131)$ in goats of District Upper Dir KPK Pakistan, with nematodes and protozoa $25.54 \%$ (47/184), and Nematodes $22.82 \%(42 / 184)$ in sheep and nematodes-nematodes $23.43 \%(30 / 148)$, and $42.18 \%(54 / 131)$ see (Table 3 ) in goats respectively.

The present study result of double parasitic infection was nearly similar to the study instigated by Ayaz et al. (2013) in small ruminants and greater than the study conducted by (Rafiullah et al., 2011). Their investigation reported higher double parasitic infection with a significant $P$ value $=0.02$. This infection rate is due to the variation present in weather grazing behaviour, and many other risk factors responsible for the prevalence of parasitism in small ruminants discussed earlier.

In the current study, triple parasitic infection in sheep of District Upper Dir were nematodes and protozoan with the prevalence rate of $25.54 \%$ (47/184) of species Fasciola spp $+H$. contortus $+T$. ovis. And H. Contortus + Trichuris +Strongyle 26.56\% (34/184) and Hemunchus spp+Strongyle spp + Faciola $s p p=17.96 \%(23 / 131)$ see (Table 4$)$ in goats. These tipple parasitic infections were also investigated by various researchers in various parts of the world, like 42.225 by (Gadahi et al., 2009), who reported the prevalence of parasitic infections in small ruminants of the species Trichurus spp+Coccidia spp and Haemonchus spp.

\section{Acknowledgements}

Acknowledgements: The authors appreciate the contribution of Mustafa Kamal (PhD Scholar Department of Zoology, Abdul Wali Khan University Mardan, Pakistan) for the production of the map of study sites. The authors thank the Researchers Supporting Project for their funding this work number (RSP-2021/232) at King Saud University, Riyadh, Saudi Arabia.

\section{References}

ASIF, M., AZEEM, S., ASIF, S. and NAZIR, S., 2008. Prevalence of gastrointestinal parasites of sheep and goats in and around Rawalpindi and Islamabad, Pakistan. Journal of Veterinary $\mathcal{E}$ Animal Sciences, vol. 1, pp. 14-17.

AWRARIS, T., BOGALE, B. and CHANIE, M., 2012. Occurrence of gastrointestinal nematodes of cattle in and around Gondar town, Amhara regional state, Ethiopia. Acta Parasitologica Globalis, vol. 3, no. 2, pp. 28-33.

AYAZ, M.M., RAZA, M.A., MURTAZA, S. and AKHTAR, S., 2013. Epidemiological survey of helminths of goats in southern Punjab, Pakistan. Tropical Biomedicine, vol. 30, no. 1, pp. 62-71. PMid:23665709.

BERRA, T.M. and AU, R.J., 1978. Incidence of black spot disease in fishes in Cedar Fork Creek, Ohio. The Ohio Journal of Science, vol. 78, no. 6, pp. 318-322.

BESIER, R.B., KAHN, L.P., SARGISON, N.D. and VAN WYK, J.A., 2016. Diagnosis, treatment and management of Haemonchus contortus in small ruminants. Advances in Parasitology, vol. 93 , pp. 181-238. http://dx.doi.org/10.1016/bs.apar.2016.02.024. PMid:27238006.

GADAHI, J.A., ARSHED, M.J., ALI, Q., JAVAID, S.B. and SHAH, S.I., 2009. Prevalence of gastrointestinal parasites of sheep and goat in and around Rawalpindi and Islamabad, Pakistan. Veterinary World, vol. 2, no. 2, pp. 51-53.

GUPTA, R.P., YADAV, C.L. and CHAUDHRI, S.S., 1987. Epidemiology of gastrointestinal nematodes of sheep and goats in Haryana, India. Veterinary Parasitology, vol. 24, no. 1-2, pp. 117-127. http:// dx.doi.org/10.1016/0304-4017(87)90136-1. PMid:3590608.

IRFANULLAH, NISAR, M.F., JADOON, A.A.K. and TABASSUM, S., 2016. Prevalence of Fasciola hepatica in domesticated cattle of District Karak, Khyber Pakhtunkhwa, Pakistan. Asian Journal of Animal Sciences, vol. 10, pp. 85-91.

LASHARI, M.H. and TASAWAR, Z., 2011. Prevalence of some gastrointestinal parasites in sheep in southern Punjab, Pakistan. Pakistan Veterinary Journal, vol. 31, no. 4, pp. 295-298.

NWOSU, C.O., MADU, P.P. and RICHARDS, W.S., 2007. Prevalence and seasonal changes in the population of gastrointestinal nematodes of small ruminants in the semi-arid zone of north-eastern Nigeria. Veterinary Parasitology, vol. 144, no. 1-2, pp. 118-124. http://dx.doi.org/10.1016/j.vetpar.2006.09.004. PMid:17127006.

PEDREIRA, J., PAZ-SILVA, A., SÁNCHEZ-ANDRADE, R., SUAREZ, J.L., ARIAS, M., LOMBA, C., DÍAZ, P., LÓPEZ, C., DÍEZ-BAÑOS, P. and MORRONDO, P., 2006. Prevalences of gastrointestinal parasites in sheep and parasite-control practices in NW Spain. Preventive Veterinary Medicine, vol. 75, no. 1-2, pp. 56-62. http://dx.doi. org/10.1016/j.prevetmed.2006.01.011. PMid:16488032.

RAFIQUE, A., RANA, S.A., KHAN, H.A. and SOHAIL, A., 2009. Prevalence of some helminths in rodents captured from different city structures including poultry farms and human population of Faisalabad, Pakistan. Pakistan Veterinary Journal, vol. 29, no. 3, pp. 141-144.

RAFIULLAH, T.A., SAJID, A., SHAH, S.R., AHMAD, S. and SHAHID, M., 2011. Prevalence of gastrointestinal tract parasites in cattle of Khyber Pakhtunkhwa. ARPN J Agr Biol Sci, vol. 6, pp. 9-15.

RAZA, M.A., YOUNAS, M. and SCHLECHT, E., 2014. Prevalence of gastrointestinal helminths in pastoral sheep and goat flocks in the Cholistan desert of Pakistan. The Journal of Animal \& Plant Sciences, vol. 24, no. 1, pp. 127-134.

SAJID, M.S., IQBAL, Z., KHAN, M.N., MUHAMMAD, G. and KHAN, M.K., 2009. Prevalence and associated risk factors for bovine tick infestation in two districts of lower Punjab, Pakistan. Preventive Veterinary Medicine, vol. 92, no. 4, pp. 386-391. http:// dx.doi.org/10.1016/j.prevetmed.2009.09.001. PMid:19782414.

SCOTT, I. and SUTHERLAND, I., 2009. Gastrointestinal nematodes of sheep and cattle: biology and control. Chichester: Wiley Blackwell.

SIDDIKI, A.Z., UDDIN, M.B., HASAN, M.B., HOSSAIN, M.F., RAHMAN, M.M., DAS, B.C., SARKER, M.S. and HOSSAIN, M.A., 2009. Coproscopic and haematological approaches to determine the prevalence of helminthiasis and protozoan diseases of Red Chittagong cattle. Pakistan Veterinary Journal, vol. 30, pp. 1-6.

SINGH, E., KAUR, P., SINGLA, L.D. and BAL, M.S., 2017. Prevalence of gastrointestinal parasitism in small ruminants in western zone of Punjab, India. Veterinary World, vol. 10, no. 1, pp.61-66. http:// dx.doi.org/10.14202/vetworld.2017.61-66. PMid:28246448.

SPEEDY, A.W., 1992. Progress in sheep and goat research. Wallingford: CAB International, pp. 179-188.

URQUHART, G.M., ARMOUR, J., DUNCON, J.L., DUNN, A.M. and JENNINGS, F.W., 1987. Veterinary parasitology. Essex: Longman Group, pp. 19 and 276-277. 